\title{
Comparison of Crack Width and Space between SCC and Conventional Concrete Beams
}

\author{
Hajdar E. Sadiku ${ }^{1}$, Zijadin Hoxha $^{2}$, Berim Osmanaj ${ }^{2}$ and Fatos Sadiku ${ }^{2}$ \\ 1. Civil Engineering and Architectural Faculty, University of Prishtina, Pristine 10000, Kosova \\ 2. Construction Company-Toning, Pristine 10000, Kosovo
}

\begin{abstract}
Concrete is a material which is in wide use in engineering especially in construction engineering and road infrastructure facilities. Development trends for high rise constructions, modern skyscrapers indicate that building such constructions with normal concretes and low consistency is impossible, therefore there is a need for concrete with high processes because of great amount of reinforcement in cross-section of concrete elements. Solution for such construction is self-compacting concrete because of its ability to fill good formworks without compaction and vibration. Considering this fact, researches for cracks, mechanical characteristics of concrete and deformations have been conducted worldwide. In this paper, we conducted an experimental research to determine the cracks on beams of self-compacting concrete and compared it with conventional concrete. The experimentally-obtained results will be presented for both types of concrete for: module of elasticity, compression strength, crack with and cracks spacing for duration failure testing time $t=400$ days.
\end{abstract}

Key words: Self-compacting concrete, conventional concrete, compression strength, cracks, modulus of elasticity.

\section{Introduction}

Self-compacting concrete, like anywhere else in the world as well as in Kosovo, has been widely used in building construction, especially in high buildings and rehabilitation of existing facilities.

For the illustration purposes of this publication, we have conducted a thorough research for different beams in order to measure their distorting features (cracks, deformations, cuts, etc.) under both short-term as well as long-term loads.

To achieve this objective, we have prepared a number of test samples and the 18 beams used have been categorized in three series:

- Series A-six beams of conventional concrete;

- Series B-six beams of self-compacting concrete;

- Series C-other six beams of conventional concrete core and coils of self-compacting concrete.

This paper aims to discuss the experimental findings

Corresponding author: Hajdar E. Sadiku, Dr., professor assistant, research field: rheology of concrete. E-mail: hajdar.sadiku@uni-pr.edu. for both types of conventional concrete and self-compacting concrete by comparing their performances for modules of elasticity [1], compression strength and the size of cracks for both types of beams during the duration testing time $t=400$ days.

Fig. 1 shows temperature measuring and porosity as well as cubical, cylindrical and prismatic samples for the two types of concrete, whereas Fig. 2 presents the relative humidity and temperature during the research period in this long lasting process [2].

\section{Testing of Modulus of Elasticity ASTM C 469}

Fig. 3 presents the testing of modulus of elasticity whereas Fig. 4 lists testing results for both conventional and self-compacting concrete [3].

\section{Static Scheme of the Beams}

The static scheme is basically a simple beam loaded with two centered forces. The cross-section dimensions of beams used in this case study are $15 \mathrm{~cm} \times 28 \mathrm{~cm}$, and their length is $3 \mathrm{~m}$, reinforced with two $\Phi-12$ bars 


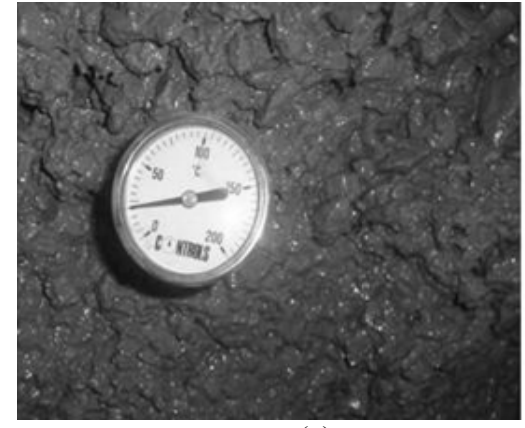

(a)

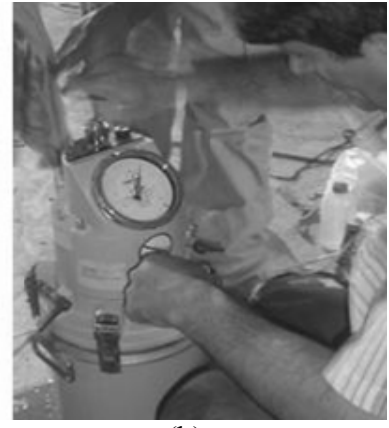

(b)

Fig. 1 Measuring the: (a) temperature and (b) porosity on concrete.

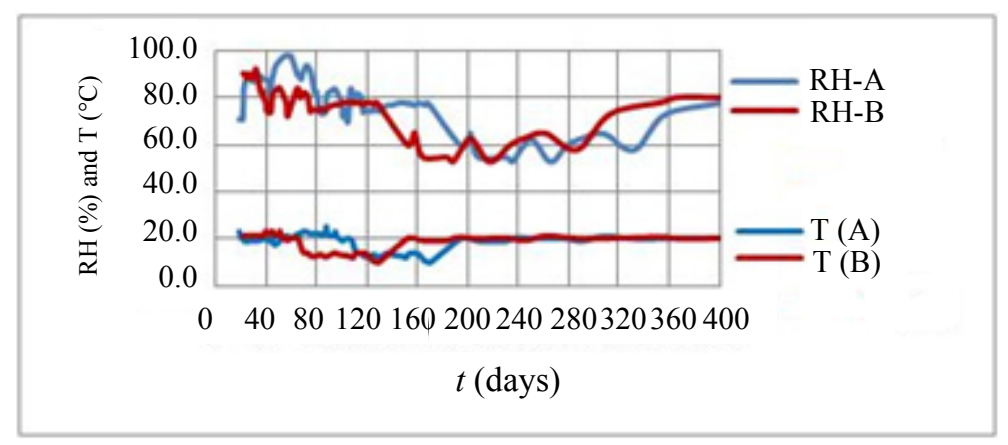

(a)

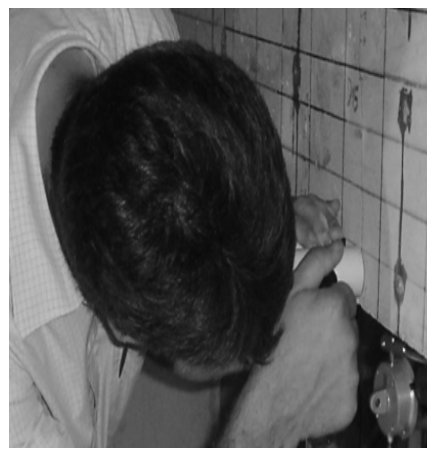

(b)

Fig. 2 (a) Relative humidity and temperature; (b) measurement of crack.

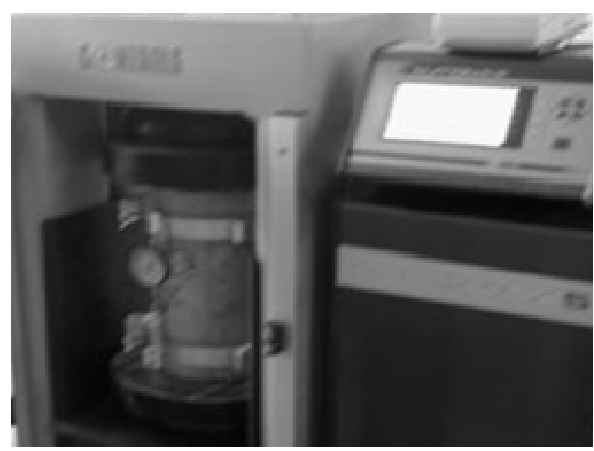

(a)

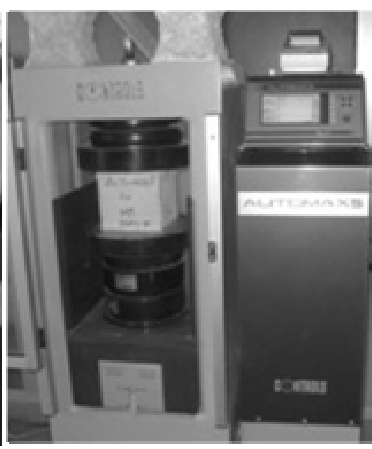

(b)

Fig. 3 Testing of: (a) modulus of elasticity; (b) compression test.

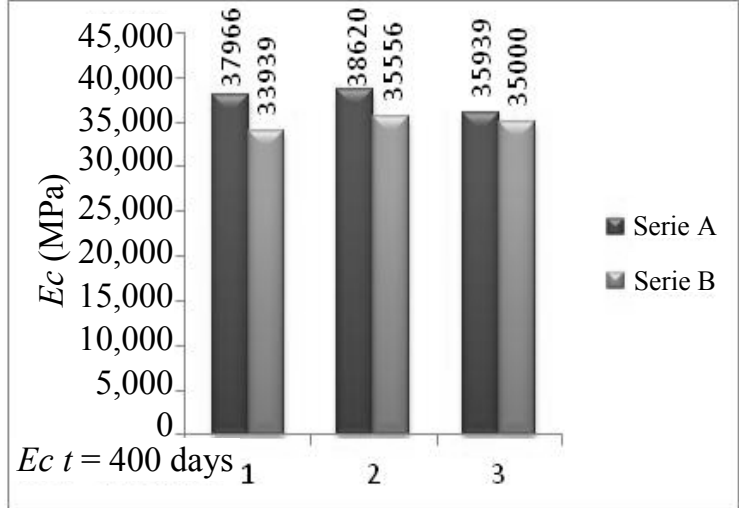

(a)

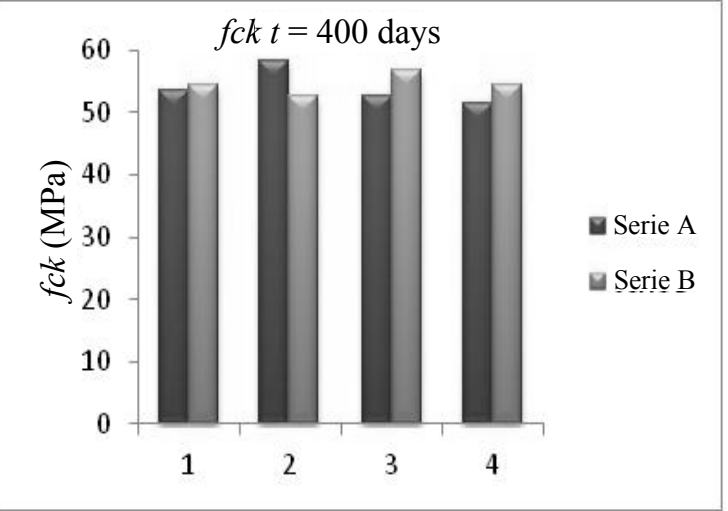

(b)

Fig. 4 Testing results of: (a) modulus of elasticity; (b) compression test. 
on the bottom (static bars) and other two $\Phi-8$ bars on the top (constructive bars) as show in Fig. 5. In Fig. 6, it is presented the failure test of the beams for testing period of $t=400$ days.

\section{Test Results of Cracks Developed on Deflected Beams}

Fig. 7 presents the results of diagrams listing the development of cracks for beams of Series A, B and C for the duration testing time $=400$ days.

The development of cracks on beams has been measured for every force incremented during the testing period (the maximal burst) by using a special microscope. The development of fresh cracks along the entire length of the beams has also been evidenced and marked for every force values that have caused those crack spacings. The size of the crack spacings is shown in Fig. 8.

In order to identify the developed cracked area on beams, the beams are split in areas of $10 \mathrm{~cm}$ horizontally by $4 \mathrm{~cm}$ vertically. Cracks spacing and their distribution samples along the beams are presented in Fig. 9.

The initial crack on Beam AI-2 occurs when acting upon it with force of $F=13 \mathrm{kN}$, thus, causing the cracks width of $w=0.06 \mathrm{~mm}$, whereas the crack on Beam AII-2 occurs after acting upon it with $F=13 \mathrm{kN}$, in which case, the cracks width will be $w=0.04 \mathrm{~mm}$.

Similarly, the initial crack on Beam B-3 occurs when acting upon it with $F=12 \mathrm{kN}$, thus, causing the cracks of width $w=0.08 \mathrm{~mm}$, while on Beam B-2, the first crack to occur was that when acting upon it with $F=12 \mathrm{kN}$ causing the crack width of $w=0.06$ $\mathrm{mm}$.

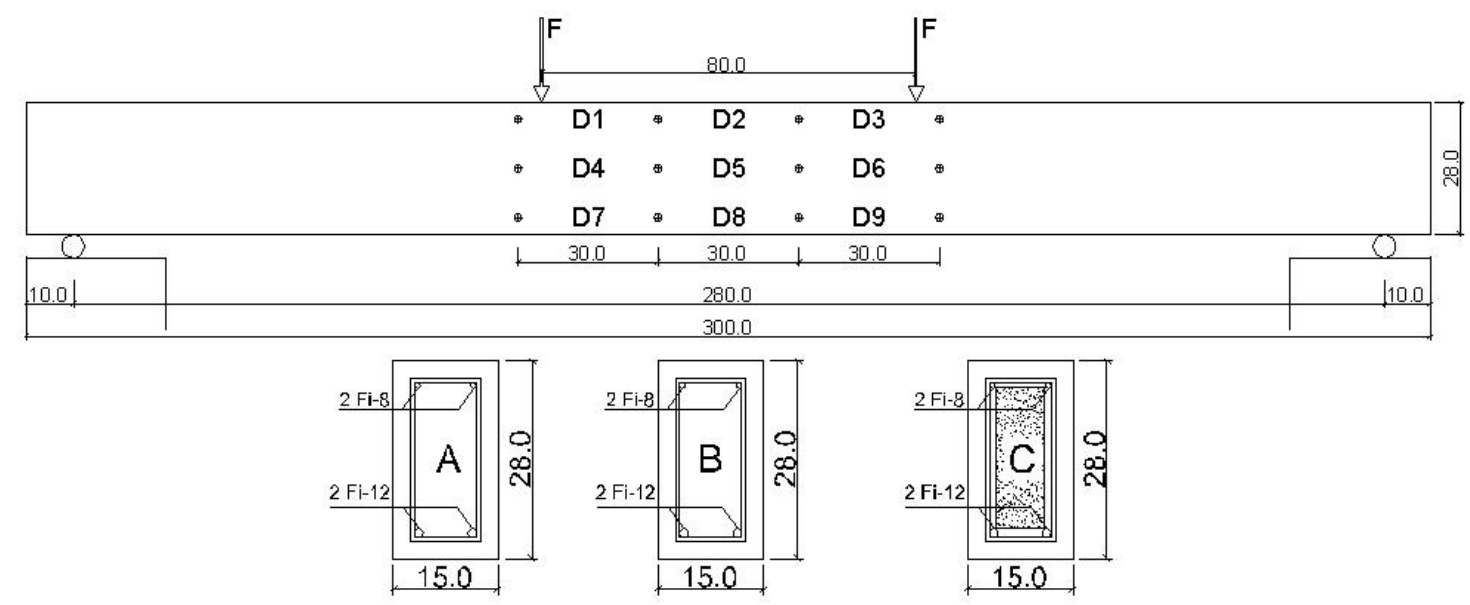

Fig. 5 Static scheme and cross-section of the beams (units in $\mathbf{m m}$ ).

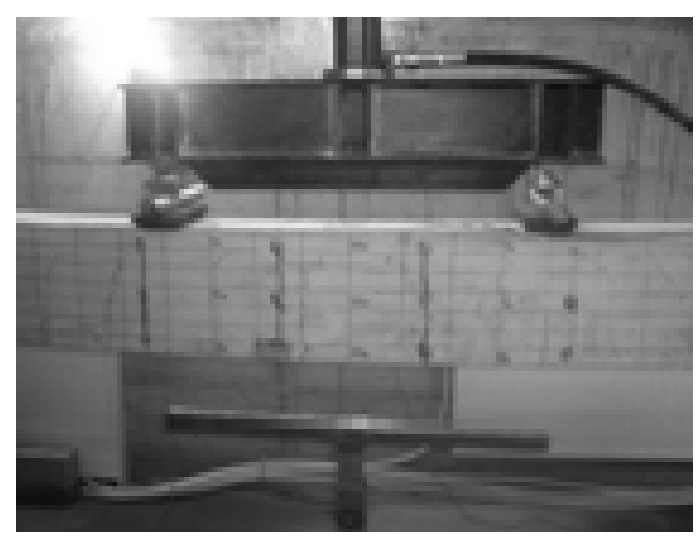

Fig. 6 Testing of beam in failure on the time $t=400$ days. 

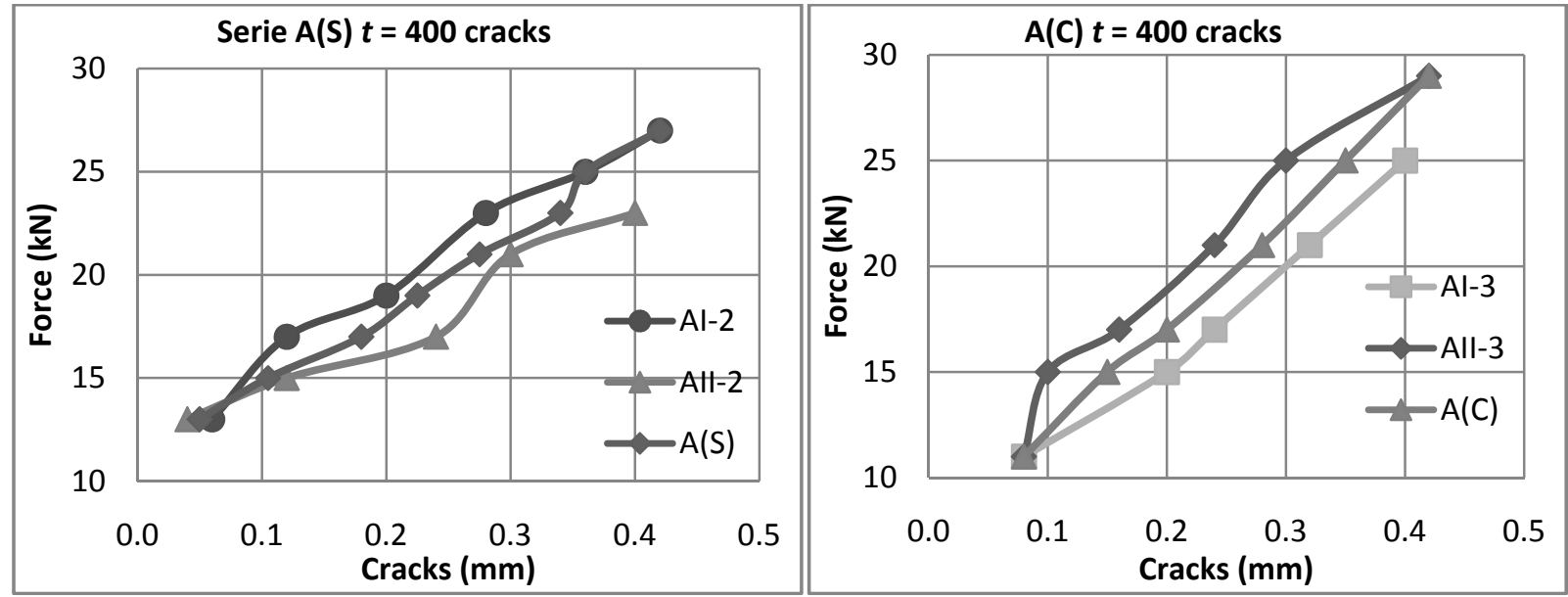

(a)
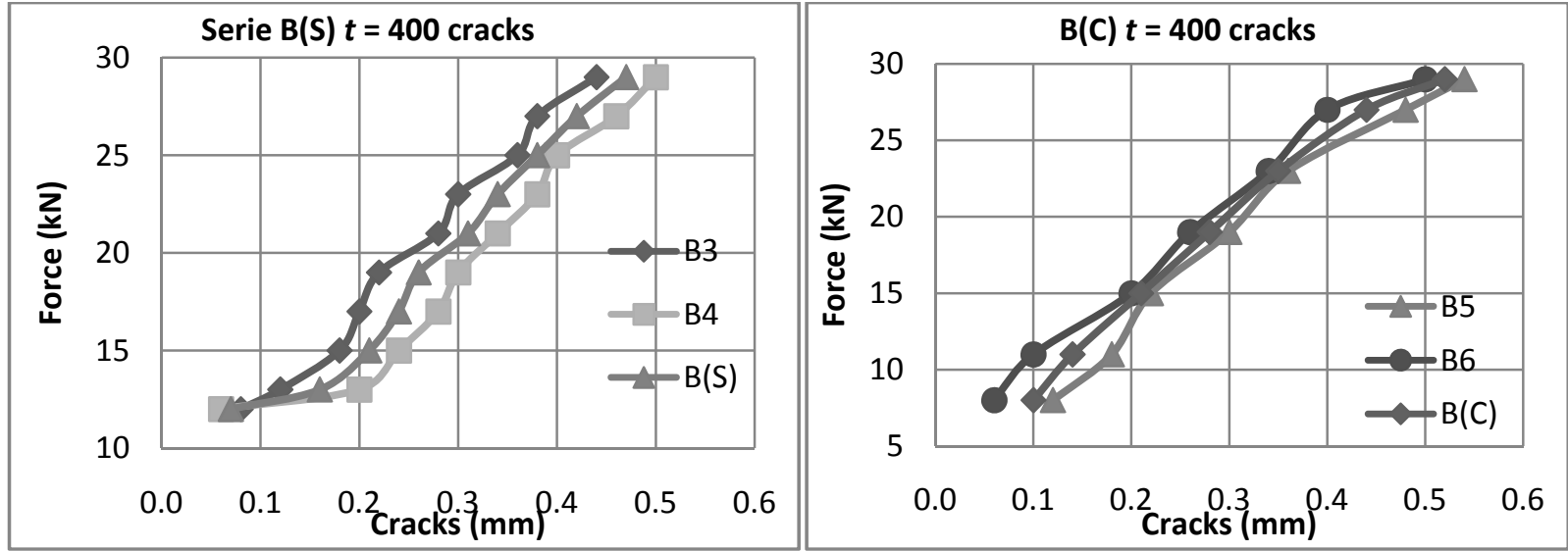

(b)
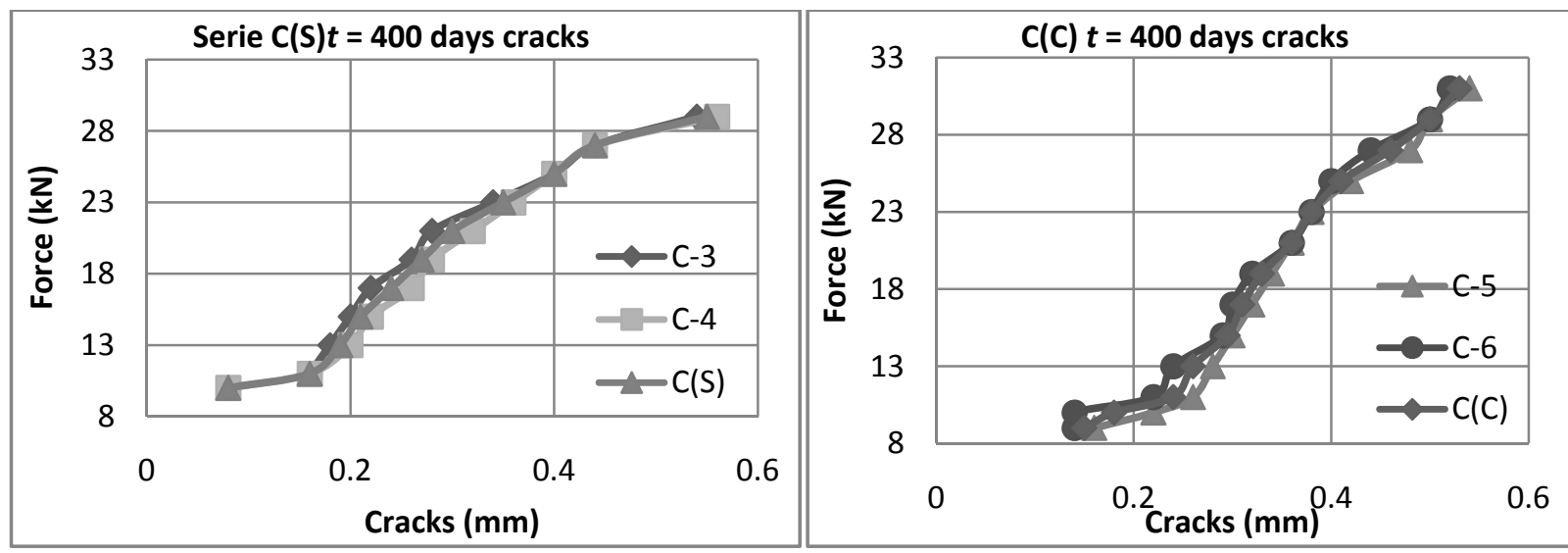

(c)

Fig. 7 Increasing size for different level of load action on beams: (a) beams of Series A; (b) beams of Series B; (c) beams of Series C.

For Beams C-3 and C-4, the following results were obtained: when acting upon $\mathrm{C}-3$ with $F=11 \mathrm{kN}$, the crack width developed was $w=0.06 \mathrm{~mm}$; whereas when acting upon $\mathrm{C}-4$ with $F=10 \mathrm{kN}$, the crack width developed was $w=0.08$.

On beams treated with expansion/deferment, the initial cracks were developed during the loading time and the same was developed on a timely basis. 

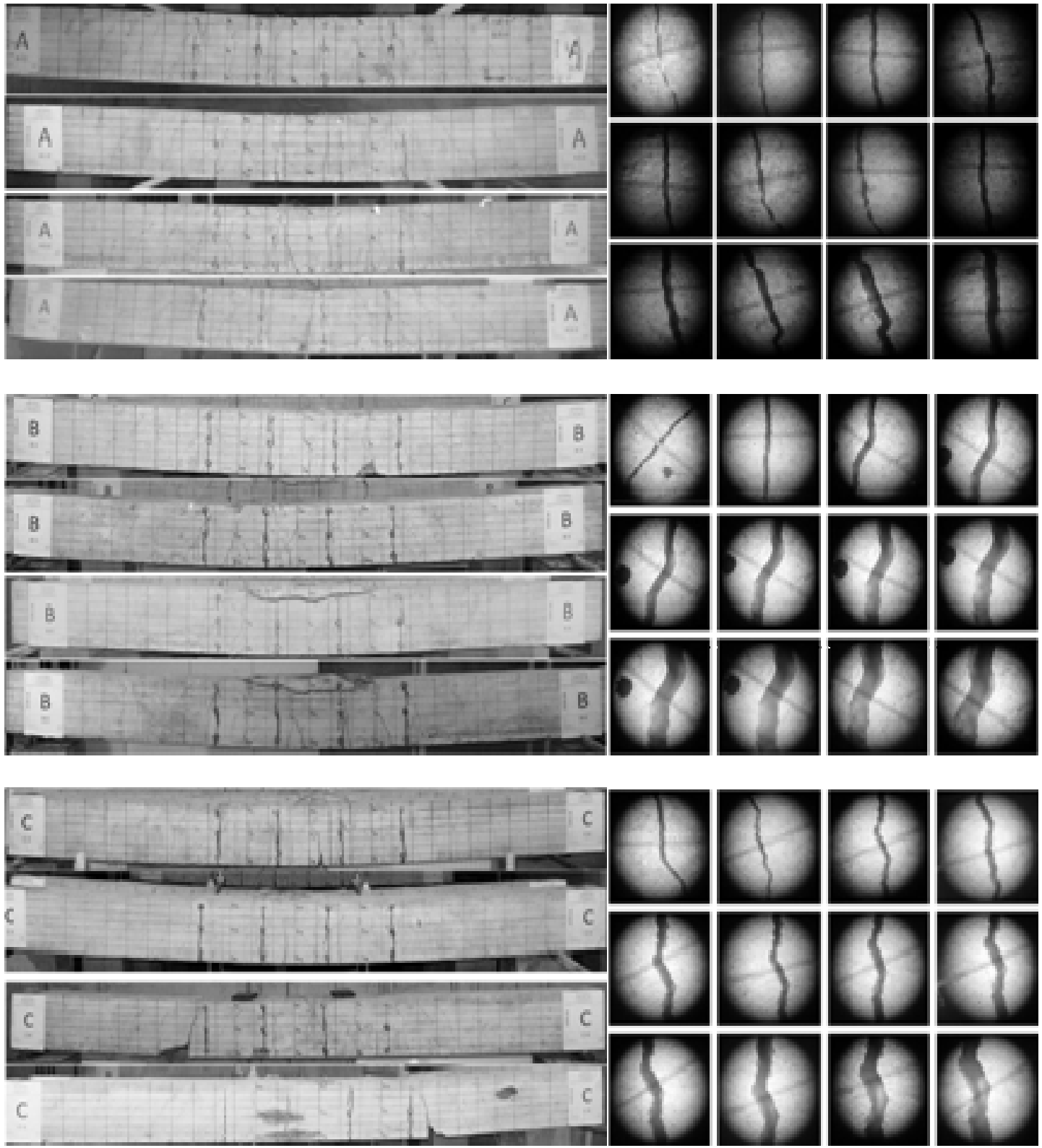

Fig. 8 Increasing the size of the cracks for different levels of force action on the beams.

\section{Comparing Crack Spacing Results}

Table 1 provides a numerical presentation of results of cracks for beams of Series A, B and C, for duration testing time of $t=400$ days (for unloaded beams-shrinking time), whereas Table 2 presents crack results for same duration testing time $t=400$ days (for loaded beams - creeping time)

Fig. 10, on the other hand, presents the diagrams of comparison of test results for beams of Series A, B and $\mathrm{C}$ (beams which are examined in shrinking for $t=400$ days, $\mathrm{A}(\mathrm{S}), \mathrm{B}(\mathrm{S}), \mathrm{C}(\mathrm{S})$ - unloaded beams and beams which are examined in crawling, for $t=400$ days $\mathrm{A}(\mathrm{C})$, $\mathrm{B}(\mathrm{C}), \mathrm{C}(\mathrm{C})$-loaded beams).

After comparing diagrams from Fig. 10, it can be noted that, for same testing period duration, beams of Series C suffered the widest cracks, while beams of Series A were affected the least. 

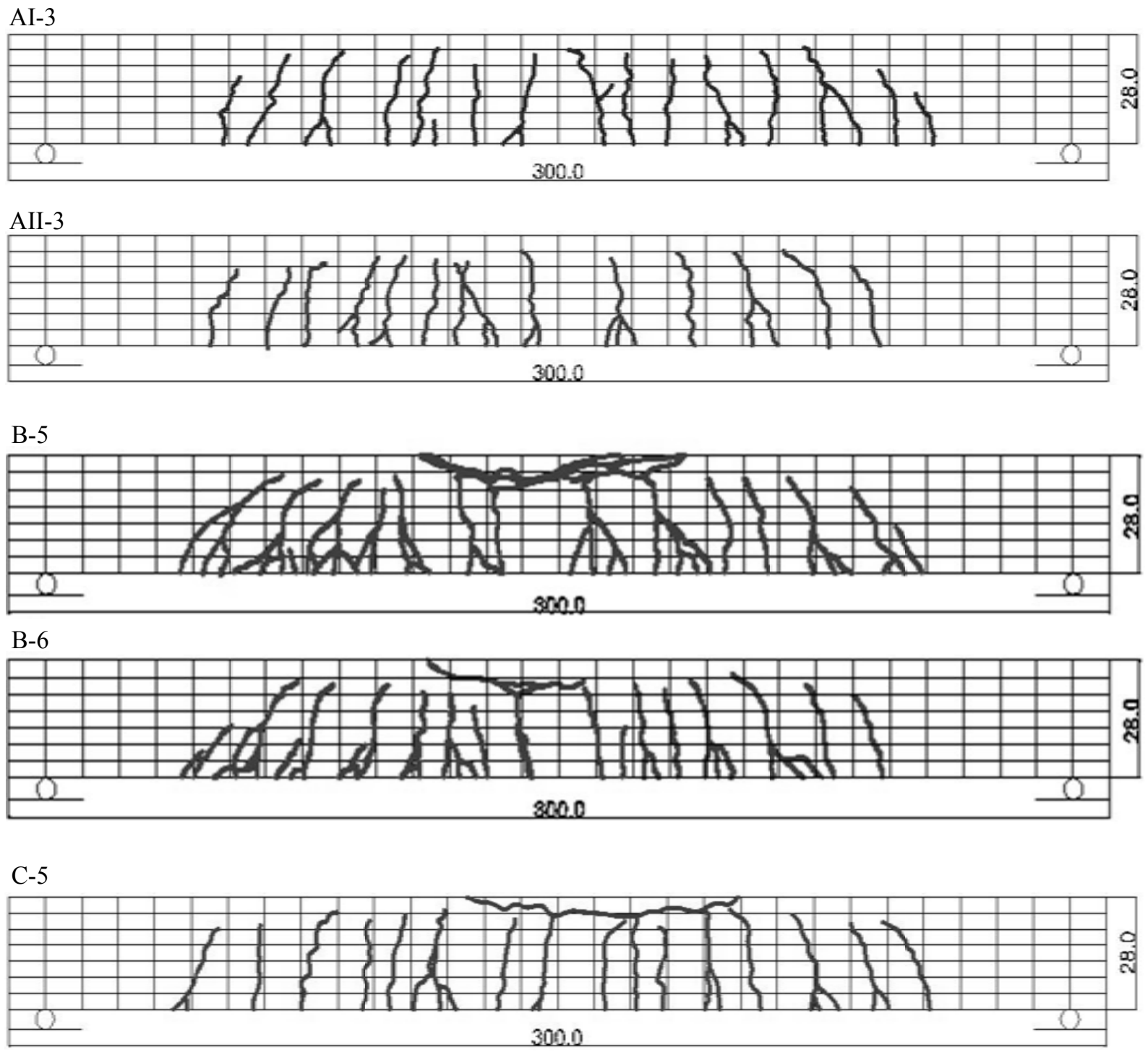

C-6

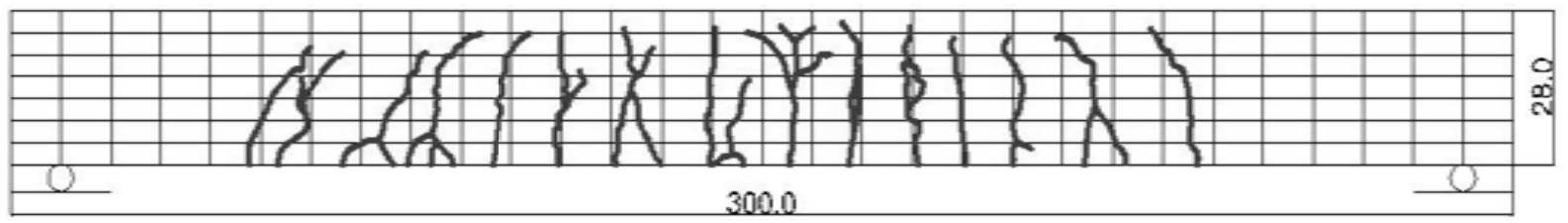

Fig. 9 Development of cracks in the length of beams (units in $\mathbf{m m}$ ).

Table 1 Comparison of results of cracks for beams of Series A(S), B(S), C(S).

\begin{tabular}{llll}
\hline & $\mathrm{A}(\mathrm{S})-\mathrm{B}(\mathrm{S})$ & $\mathrm{A}(\mathrm{S})-\mathrm{C}(\mathrm{S})$ & $\mathrm{B}(\mathrm{S})-\mathrm{C}(\mathrm{S})$ \\
\hline Differ on $\%$ & 20.78 & 30.61 & 16.76 \\
\hline
\end{tabular}

Table 2 Comparison of crack results for beams of Series $A(C), B(C), C(C), t=400$ days.

\begin{tabular}{llll}
\hline & $\mathrm{A}(\mathrm{C})-\mathrm{B}(\mathrm{C})$ & $\mathrm{A}(\mathrm{C})-\mathrm{C}(\mathrm{C})$ & $\mathrm{B}(\mathrm{C})-\mathrm{C}(\mathrm{C})$ \\
\hline Differ on $\%$ & 33.01 & 33.93 & 16.11 \\
\hline
\end{tabular}




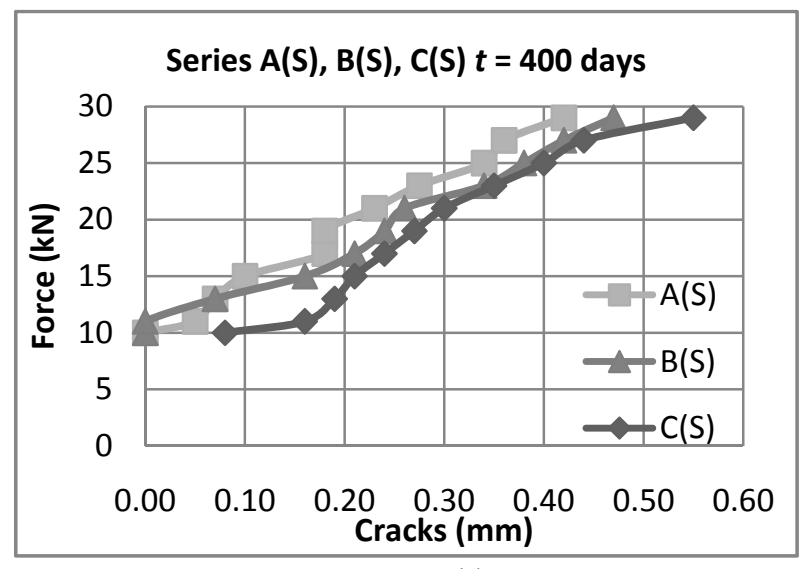

(a)

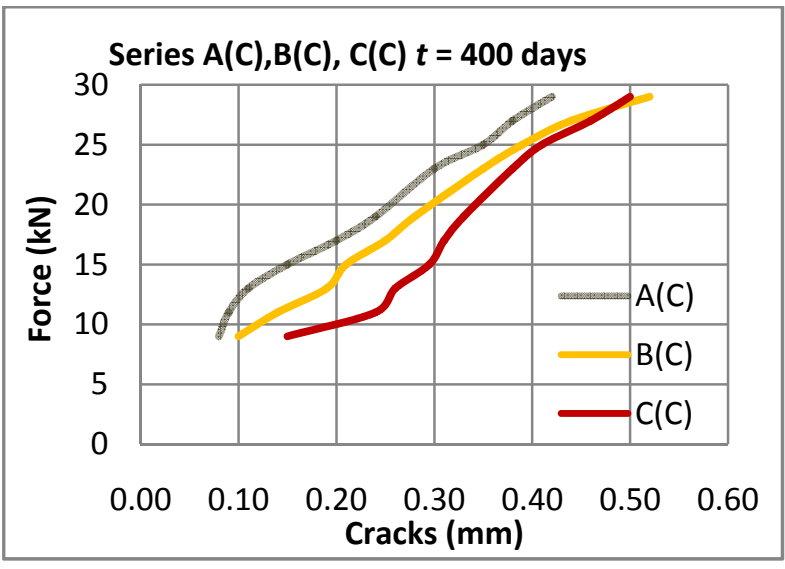

(b)

Fig. 10 Comparison of cracks diagrams: (a) Series A(C), B(C), C(C) (loaded beams-crawling); (b) Series A(S), B(S), C(S) (unloaded beams-shrinkage).

\section{Conclusions}

Based on the results obtained during the experiment, the following conclusions can be drawn:

(1) Self-compacting concrete has smaller modulus of elasticity than conventional concrete;

(2) Small difference in results was encountered between beams of Series B and C, averaged 16\%, while the largest difference in results was for beams of Series $\mathrm{A}$ and $\mathrm{C}$;

(3) The slightest difference was encountered when comparing results of shrinkage-treated beams versus beams treated during crawling;

(4) It is noted that, after deflection, the distance between the cracks and their development on the beams is more regular and denser on beams of self-compacting concrete, indicating more homogeneous work in the entire length of these beams;

(5) Greater deflective force is required on beams of self-compacting concrete.

\section{References}

[1] H. Okamura, K. Ozawa, Mix design for self-compacting concrete, Concrete Library of JSCE (Japan Society of Civil Engineers) 25 (6) (1995) 107-120.

[2] H. Sadiku, F. Jagxhiu, Analiza e deformimeve në procesin kohëgjatë në varësi të klasës së betonit te elementet beton (Stress-Strain analysis on long-term process where hangs of concrete class for axially loaded concrete elements), in: Proceedings of Symposium in Prtishtina 2005, 2005, pp. 629-641. (in Albanian)

[3] H. Sadiku, Analiza e sforcimeve dhe deformimeve në procesin kohëgjatë në shufrën e betonarmesë sipas EC-2 (Stress-Strain analysis on long-term process of concrete column under the EC-2), Master Thesis, University of Prishtina, Prishtinë, 1998. (in Albanian) 